\title{
The nature of carbon flux in various ecosystem types in the Biduk-Biduk Karst Region, Berau District, East Kalimantan
}

\author{
Danardono Danardono ${ }^{1, *}$, Eko Haryono ${ }^{1}$, and Margareta Widyastuti $^{1,2}$ \\ ${ }^{1}$ Karst Research Group, Faculty of Geography, Universitas Gadjah Mada, Indonesia \\ ${ }^{2}$ Laboratory of Environmental Hydrology and Climatology, Faculty of Geography, Universitas Gadjah Mada, Indonesia
}

\begin{abstract}
Biduk-Biduk Karst Region has great potential to absorb and store organic carbon in vegetation and soil as well as to absorb inorganic carbon through the process of dissolution. The area has important economic value in supporting the REDD Program in Berau District. The purpose of this study is (1) to identify the amount of carbon stocks in various ecosystems; and (2) to identify the amount of carbon uptake in various ecosystems in the study area. Carbon stocks are computed based on four carbon sinks, i.e., above ground biomass, underground biomass, litter, and soil organic matter using the standard measurement method of SNI 7724: 2011. Carbon sequestration is calculated based on the input of carbon from the atmosphere to ecosystems through litter fall and karstification process and the output of carbon from the ecosystem to the atmosphere through soil respiration. Litter fall is measured using the litter trap method. Karstification is measured with standard limestone tablet method. Soil respiration is calculated with the closed chamber method. The results show that the ecosystems in the Biduk-Biduk Karst Region have a potential carbon stock of $4,800.92$ tons/ha with the largest value in the secondary tropical forest of 732.6 tons/ha and the lowest value in the teak forest plantation of 358.2 tons/ha. Ecosystems in the Biduk-Biduk Karst Region have a potential carbon sequestration of 37.33 tons/ha/year with the largest contribution in the primary tropical forest of 7,63 tons/ha/year.
\end{abstract}

\section{Introduction}

Efforts to reduce global carbon emissions have been initiated in various parts of the world including Indonesia. Presidential Regulation No. 61: 2011 on the National Action Plan for Greenhouse Gas Emission Reduction (RAN-GRK) is a concrete action taken by Indonesia to reduce carbon emissions. The key points of RAN-GRK contents are Indonesia's commitment to reduce $26 \%$ of its national carbon emissions and a mandate to each region to develop Local Action Plans for the reduction of Greenhouse Gases (RAD-GRK). RAD-GRK was established at the provincial as well as at the district/city levels.

The East Kalimantan Province is one of the regions that have committed to the reduction of carbon emissions through Governor Regulation No. 39: 2014 on RADGRK in the East Kalimantan Province. One of the programs that have been initiated by this province is Program Karbon Hutan Berau (PKHB) or Carbon Forest Berau. PKHB was begun as an effort to reduce carbon emissions from the forestry sector and to conserve the forest ecosystems in Berau District. The main target of PKHB as stipulated in its objectives is to reduce emissions and to increase carbon stocks of 10 million tons $\mathrm{CO}_{2}$ in the forestry sector.

The Biduk-Biduk Karst Region at the eastern area of Berau District is one of the areas that will be developed in an effort to reduce carbon emissions. The availability of tropical forest ecosystems in this karst region gives this zone a double potential in the process of carbon sequestration and storage in the form of organic and inorganic carbon. Tropical forest ecosystems are capable of storing 200-500 tons/ha of organic carbon in vegetation and litter [2].

The sequestration and storage process of organic carbon in the Biduk-Biduk Karst Region occurs because of the scope of the ecosystem. Interaction between the abiotic, the biotic, and the cultural environment causes the occurrence of the process of carbon transfer and storage. Organic carbon ecosystems are deposited in four carbon pools: above ground biomass in the vegetation, subsurface biomass in the root zone, litter biomass, and soil organic matter $[13,15,18]$. The deposits of carbon ecosystems are displaced in between carbon sinks from the atmosphere into the ecosystems. The organic carbon process can be a form of organic carbon uptake to the ecosystem through litter fall and can be a form of organic carbon output to the atmosphere through soil respiration $[6,15,19]$.

Another potential carbon sequestration system in the Biduk-Biduk Karst Region that is often overlooked in carbon trading mechanisms is inorganic carbon sequestration in the karst region. The importance of the karst region in the global carbon cycle has been studied since the 20th century. The ability of the karst region to absorb a lot of carbon from the atmosphere occurs through the carbonate dissolution process $[6,16]$. In addition, carbonate rock is the largest store of inorganic carbon on the earth's surface.

\footnotetext{
Corresponding author: danardono91@gmail.com
} 
Carbon flux assessment at the ecosystem level needs to be done in the Biduk-Biduk Karst Region because of the variation of carbon values in ecosystems because of the influence of the type of vegetation, the climate, the soil, and human activity [18]. Therefore, it is important to conduct a carbon assessment on the ecosystem scale to check the variation of the carbon flux value at the ecosystem level. Based on this description, it is vital to accomplish research that aims (1) to identify the amount of carbon stocks in various ecosystems in the study area; and (2) to identify the amount of carbon uptake in various ecosystems in the study area.

\section{Study area}

This research was located in the Biduk-Biduk Karst Region which is administratively located in Berau District, East Kalimantan Province. The Biduk-Biduk Karst Region is included in the SangkulirangMangkalihat Karst Region. It has a morphology of conical karst hills with the slope strata as an indication of marine terrace formation. The morphology of conical karst hills becomes characteristic of the coastal karst type in the Sangkulirang-Mangkalihat Karst Region with lithology of coral limestone and crystalline limestone in the Domaring Formation (Tmpd). The location of the Biduk-Biduk Karst Region near the equator causes this area to be included in tropical climate zone. The variation of abiotic environmental conditions produces the typical ecosystem conditions in this region. The absence of dry months (rainfall $<100 \mathrm{~mm} / \mathrm{month}$ ) and relatively warm temperatures through each year characterize the Af climate (Koppen classification) in this region.

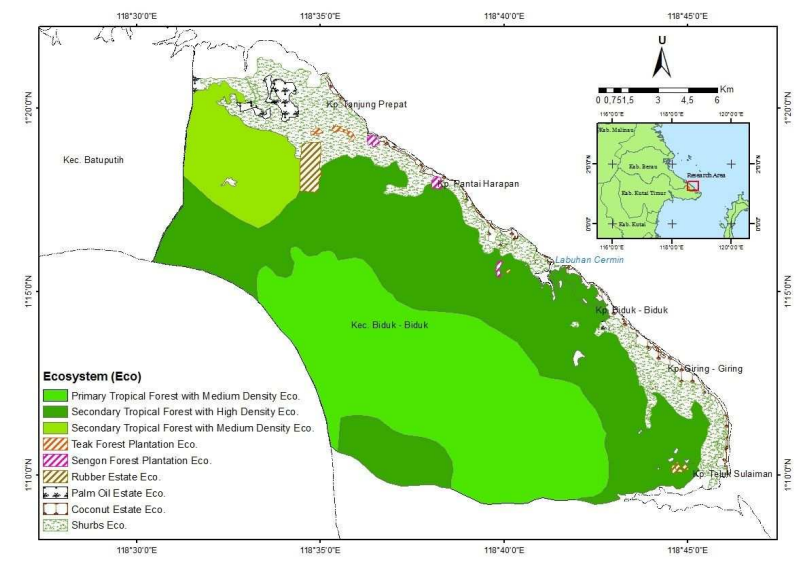

Fig. 1. Ecosystem Distribution in Biduk-Biduk Karst Region.

The Biduk- Biduk Karst Region has nine terrestrial ecosystems as a result of interactions among the three components of the abiotic, the biotic, and cultural environments. These ecosystems are spreading with the dominance of tropical forest ecosystems belonging to the Dipterocarpaceae forest type, both primary and secondary. Other ecosystems formed by human activities both through crop cultivation and through built land area are scattered throughout the Biduk-Biduk Coastal Area. The distribution and types of terrestrial ecosystems in the Biduk-Biduk Karst Region can be seen in Figure 1.

\section{Methods}

Carbon stocks and sequestration were measured in nine terrestrial ecosystems in the Biduk-Biduk Karst Region. Measurements were conducted between 2015 and 2016. Measurements of carbon stocks were carried out in four carbon pools: above ground, subsurface, litter, and soil carbon. Carbon stocks of each ecosystem in the BidukBiduk Karst Region were calculated based on standard method of SNI 7724: 2011. The value of aboveground, subsurface, and litter carbon stocks were calculated by regression analysis between the value of carbon stocks in actual field measurement and the NDVI. NDVI was obtained by SPOT 6 image processing in 2016 with spatial resolution of \pm 6 meters. The value of soil carbon stock was calculated using laboratory measurement.

Carbon sequestration was measured with regard to the carbon input and output. Organic carbon input was quantified through the litter fall process and the inorganic carbon input was computed through the karstification process. Carbon output was measured via the soil respiration processes. The measurement of litter fall was conducted by using litter traps $(2 \times 2$ meters $)$ for a month. The measurement of the karstification or dissolution rate was based on the standard limestone tablets method. Limestone tablets were planted in the soil at depths of $20 \mathrm{~cm}$ and $60 \mathrm{~cm}$ and above ground at an altitude of $\pm 100 \mathrm{~cm}$ for one year (October 2015 until August 2016). Soil respiration was measured by the closed chamber method based on Soil Quality Test Kit Guide USDA, 1999, where a closed compartment is installed above the ground with part of it embedded in the soil. The respiration of the soil within the closed cavity was measured with soil gas detector with interval for \pm 7 days.

\section{Results}

\subsection{Carbon stocks}

Organic carbon stock of the ecosystem is present in four carbon pools of above ground, subsurface, litter, and soil organic matter. Above ground carbon stock is approached with vegetation density values depicted by NDVI. The Biduk-Biduk Karst Region shows a high vegetation density or NDVI with intervals ranging from 0.584 until 0.877 . The distribution of NDVI in the Biduk-Biduk Karst Region can be seen in Figure 2.

NDVI distribution value can reflects the value of above ground carbon stocks where the increasing value of the vegetation index is followed by the increasing value of above ground carbon stocks. This refers to the regression result between the value of carbon field measurement and the value of NDVI (Figure 3). The result of regression analysis used to construct a carbon value calculation model has a high determination coefficient on exponential regression equation. 


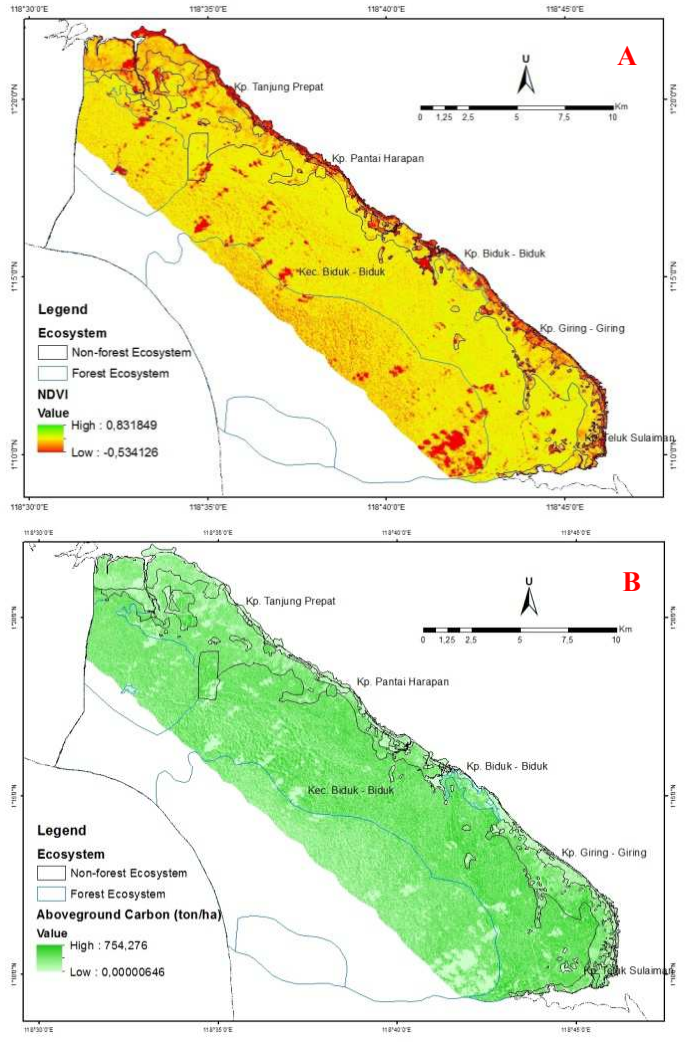

Fig. 2. NDVI Distribution (A) and Aboveground Carbon (B) in Study Area.

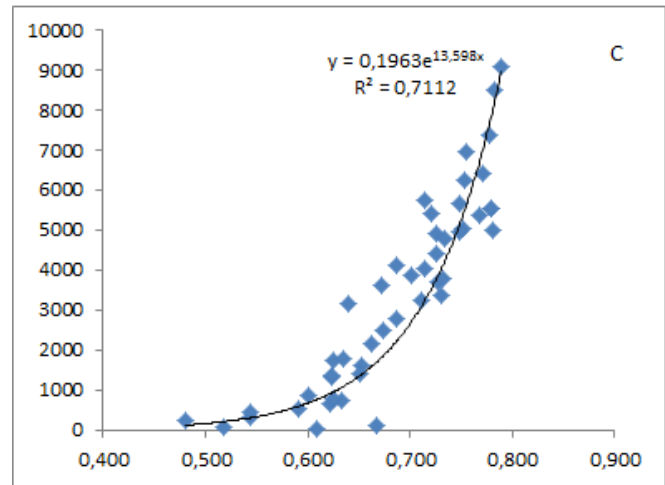

Fig. 3. Scatter Plot between NDVI and carbon stocks.

The total value of carbon stocks in the Biduk-Biduk Karst Region shows the highest value in the high density of the secondary tropical rainforest ecosystems and the lowest value in teak plantation ecosystems. The total value of carbon stocks in study area is influenced by the condition of all four carbon pools. The carbon stock condition that most affects the total value of carbon stocks is in the soil carbon pool. The effect of the soil carbon pool on the total carbon stock of this ecosystem is seen in the proportion of the carbon ecosystem composition in which the carbon stock in all ecosystems is dominated by the soil carbon pool. The composition of the carbon stock ecosystem in the study area can be seen in Figure 4.
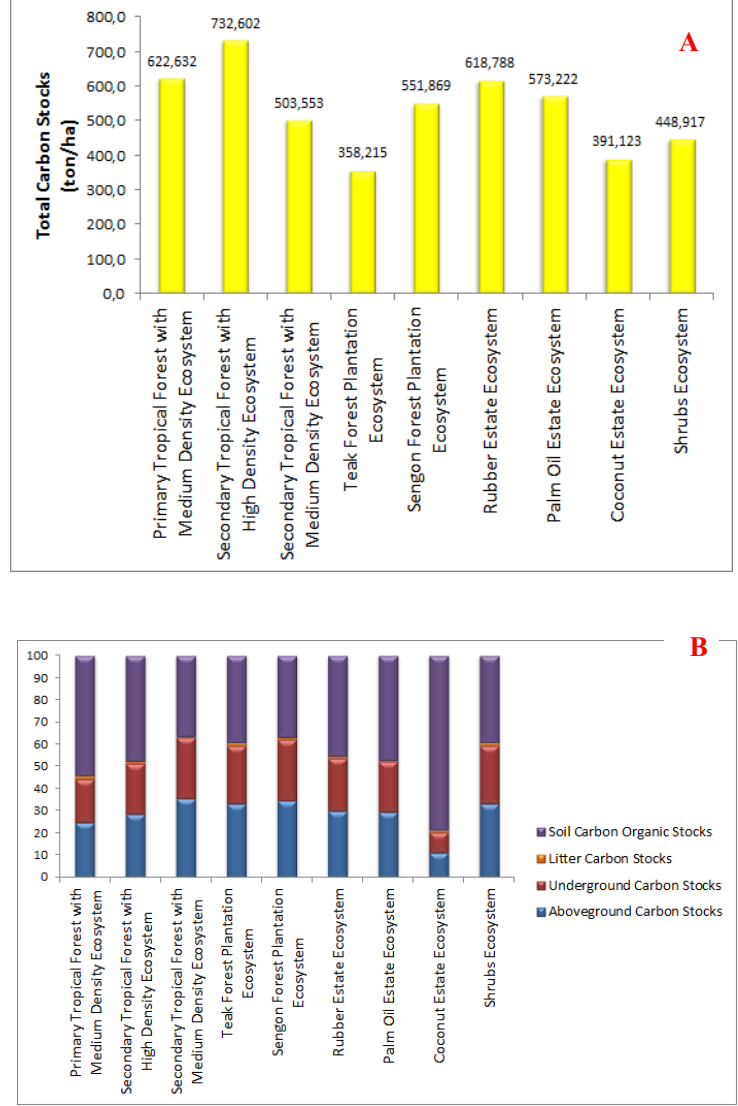

Fig. 4. Value of total carbon stocks (A) and carbon stocks composition (B).

\subsection{Carbon sequestration}

The carbon input of the ecosystem in the Biduk-Biduk Karst Region consists of both organic and inorganic carbon sequestration. The process of organic carbon absorption is founded on the litter fall, which is a main input of litter and soil carbon stocks. The value of litter fall is varied in each ecosystem in the Biduk-Biduk Karst Region. The largest litter production is found in the high density of the secondary tropical rainforest ecosystem and the lowest value is found in the palm oil and shrub plantation ecosystems. The main factor influencing litter production is vegetation density. The denser the vegetation, the more litter is produced. The litter production value in each ecosystem in the Biduk-Biduk Karst Region is presented in Figure 5.

The inorganic carbon absorption process happens through the karstification or dissolution process. Calculated results show that the largest inorganic carbon absorption process occurs in the karst plain. The slope conditions, along with the thickness of the limestone, causes a higher infiltration and percolation intensity than the solutional marine terrace with steep slopes. Because of this condition, the highest inorganic carbon absorption is in the non-forest ecosystem like the palm oil plantation ecosystem and the teak plant ecosystem. The location of non-forest ecosystems that are mostly located in the karst plain area make inorganic carbon sequestration higher here than in the tropical rainforest ecosystems that spread up to the solutional marine 
terrace area. The value of the inorganic carbon sequestration can be seen in Figure 6.

The carbon in the ecosystem is released back into the atmosphere naturally through the soil respiration process. Soil respiration is done to balance the carbon content in the soil so the value of soil respiration is strongly influenced by soil C-organic forming factors such as temperature, humidity, texture, and soil organic matter. Differences in the soil characteristic in each ecosystem causes variations in soil respiration value. The results show that the highest soil respiration is found in the high density of the secondary tropical rainforest ecosystems and the lowest value is found in the rubber plantation ecosystems. The greater respiration value in high density tropical rainforest ecosystems due to the intensive carbon formation process in the soil is indicated by the high soil organic matter. Optimum conditions of temperature and humidity and the availability of organic materials in large quantities make the soil carbon formation process more intensive. The soil respiration values in each ecosystem can be seen in Figure 7.

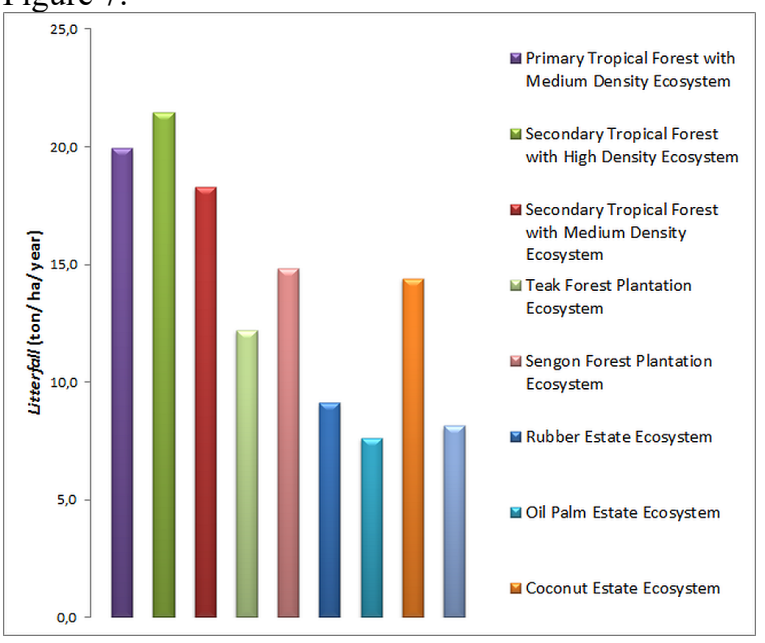

Fig. 5. Value of Litter fall on Various Ecosystem Types

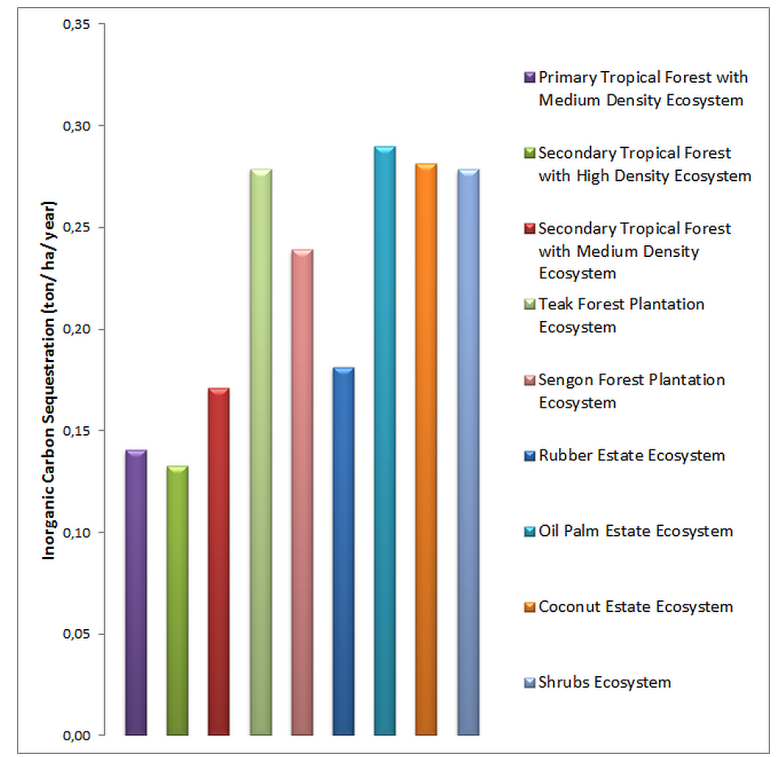

Fig. 6. Value of inorganic carbon sequestration on various ecosystem types.

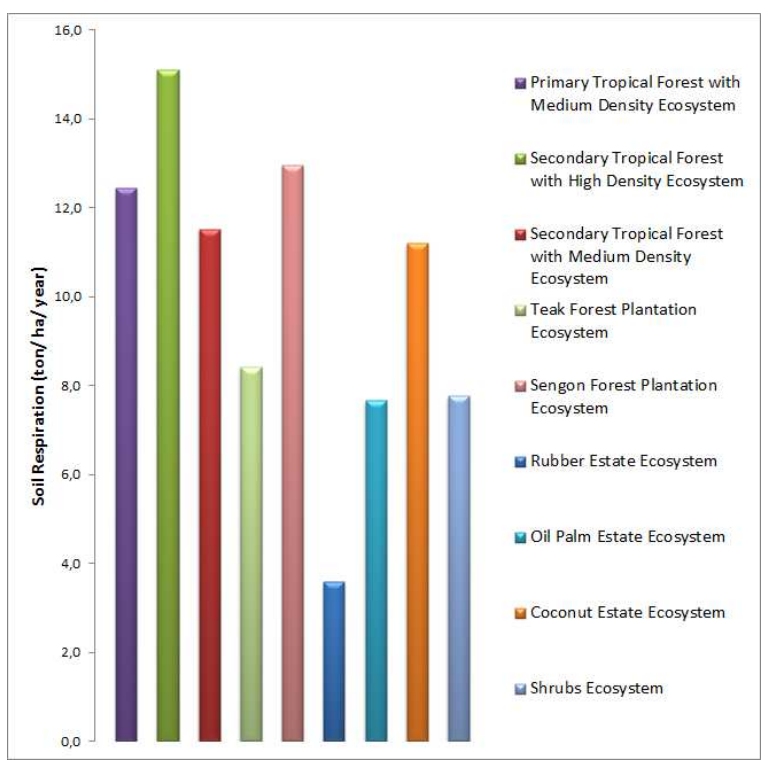

Fig. 7. Value of soil respiration on various ecosystem types.

\section{Discussions}

The occurrence of carbon flux in the Biduk-Biduk Karst Region is very dynamic. The dynamics of carbon in the Biduk-Biduk Karst Region can occur within the scope of the biosphere and the ecosystem scale. The dynamics of carbon in the ecosystem scale occur as a result of the interaction between the abiotic, the biotic, and the cultural environmental components. The interaction between the abiotic and the biotic environments in the Biduk-Biduk Karst Region results in the natural exchange of carbon. The dynamics of carbon in the ecosystem include the input, exchange, output, and storage of carbon. The dynamics of carbon occurring in the ecosystem of the Biduk-Biduk Karst Region are presented in Figure 8.

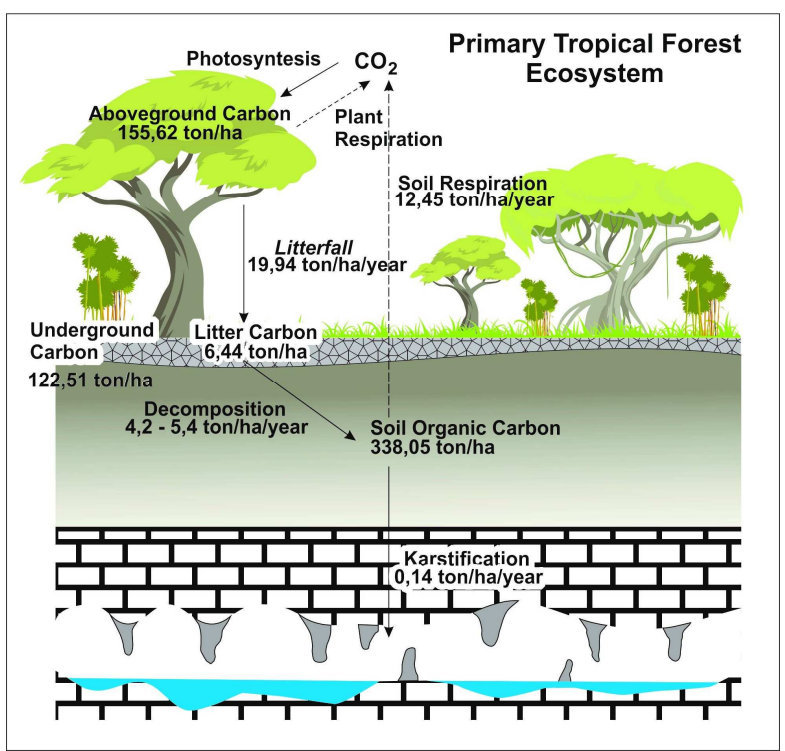

Fig. 8. Carbon Dynamic in Primary Tropical Rainforest.

Carbon dynamics in the Biduk-Biduk Karst Region begins with the process of carbon sequestration from the atmosphere by plants through the process of 
photosynthesis. The value of carbon sequestration by plants can be seen from the biomass value. Plant biomass in the Biduk-Biduk Karst Region is high, indicating that carbon sequestration for photosynthesis is also high [10]. The potential of above ground carbon stocks in the Biduk-Biduk Karst Region has lower value than the above ground carbon stocks in the non-karst tropical forest ecosystems. The location of the forest ecosystem in the karst region causes the above ground carbon stocks to be of lower value than those in the non-karst tropical forest ecosystem $[2,3,13]$. This condition happens because plants that live in the karst region have ability to withstand dry surface conditions and usually have slower rates of growth and development.

The potential value of above ground carbon stocks in the Karst Biduk-Biduk Region is considerable between forest and cultivation ecosystem. Heterogeneous vegetation conditions in the tropical forest ecosystem in the Biduk-Biduk Karst Region cause the carbon stocks in this ecosystem to be greater than the cultivated ecosystem that has more homogeneous vegetation. This condition happens because each vegetation has different carbon absorption capabilities so a combination of different types of vegetation produce larger biomass values than a single vegetation type [18,19].

Carbon stocks in vegetation can be released back into the atmosphere through the process of plant respiration. The rate of plant respiration can be minimized through the process of reducing plant components by the mechanisms of leaf blemishes and twigs known as litter fall. The value of litter fall in the forest ecosystem in the Biduk-Biduk Karst Region is relatively elevated and thus it can play a role in reducing carbon emissions to the atmosphere. The larger litter fall produced by plants can reduce carbon emissions into the atmosphere through plant respiration [19]. The litter fall value in the karst tropical forest ecosystems in the study area are comparatively similar to the non-karst forest ecosystems in Kalimantan [13], but lower than the forest ecosystems in Java [6] and higher than the temperate forest ecosystem in America [20]; Sweden and Germany [12]. The differences in litter produced in the tropical forest ecosystems vis-a-vis temperate forest ecosystems are caused by micro-climate conditions. The high humidity and warm temperatures combined with the absence of extreme seasonal differences in the study area cause the temperature and humidity of the forest to be maintained. Thus, the measure of tree components such as leaves, fruits and twigs that drop to the ground remains relatively constant throughout the year.

The rate of litter fall in each ecosystem in the BidukBiduk Karst Region shows variation based on vegetation density. The denser the vegetation, the higher the litter fall value in the Biduk-Biduk Karst Region. This condition happens because of the competition in receiving solar radiation for photosynthesis [9]. The competition for solar radiation makes plants that do not receive optimal radiation dry and shed their leaves to the ground. This dropped part of the plant is stored as litter above the soil surface to form carbon litter in every ecosystem in the Biduk-Biduk Karst Region.
The value of litter carbon stock in the study area is very high. The value of litter carbon stocks in tropical forest ecosystems in the study area has greater value than non-forest ecosystems, both cultivated and other manmade ecosystems. This result echoes [14] work achieved in Japan. The high percentage of organic carbon in the form of litter is likely the result of the high litter fall rate of deciduous trees in this area.

Almost all the value of the litter fall in the ecosystem study area is greater than the stored carbon stocks in the litter over the soil surface. This indicates that the litter decomposition rate in the study area tends to be large and intensive. The litter decomposition rate in the study area has the same value as the decomposition rate in the tropical forest ecosystem that has been computed in previous research in Kalimantan of 4.2-5.4 ton/ha/year [13]. This value indicates that $\pm 80 \%$ of the plant litter is decomposed by microorganisms and turned into stored carbon in the soil [13].

The litter decomposition process becomes the main source of stored carbon stocks in soil. The largest soil carbon stocks in this study area are found in tropical rainforest ecosystems that have relatively same value as other forest ecosystems in southeastern Asia karst region [4]; Southwestern China [16]; Xishuangbanna China [11]. The amount of soil carbon stocks in tropical rainforest ecosystems in the Biduk-Biduk Karst Region is due to the high availability of litter or organic matter in this ecosystem.

Carbon soil stocks in the Biduk-Biduk Karst Region undergo an exchange process from the soil to the atmosphere and from the soil to rocks. The process of exchanging carbon from the soil to the atmosphere occurs through the process of soil respiration. Soil respiration is a form of carbon emission produced by ecosystems and released into the atmosphere. In the study area, soil respiration is controlled by two processes, soil carbon storage and karstification. The value of soil respiration in the Biduk-Biduk Karst Region is relatively high as a result of the impact of the greater value of soil carbon stock. Soil respiration serves to balance the value of carbon stocks contained in the soil so ecosystems with elevated soil carbon stocks will have higher soil respiration $[6,15]$. Soil respiration in the Biduk-Biduk Karst Region shows a greater value in the forest ecosystem than in the non-forest ecosystem. The high soil respiration in forest ecosystems compared to non-forest ecosystems also occurs in other areas in Gunungkidul [6], West Java [8], and Central Sulawesi [1].

Another factor that contributes to soil respiration in the study area is the karstification process. As suggested by $[5,17]$ the process of limestone dissolution utilizing carbon dioxide from the atmosphere and the soil creates the soil carbon stocks used for this process. Reduction soil carbon stocks for karstification causes the decrease of the release of carbon into the. This condition is reinforced, because of which the value of soil respiration in the ecosystem study area has a smaller value than the value of soil respiration in the non-karst tropical rainforest ecosystem in Sulawesi Tengah, Indonesia [1]; Guilin, China [7]; and West Java, Indonesia [8]. This 
condition only happens in ecosystems located in the karst region, so it can be said that karst landscape also contributes to the reduction of carbon emissions to the atmosphere.

\section{Conclusion}

The Biduk-Biduk Karst Region have a great potential to store some carbon in their terestrial ecosystems with the total carbon stock of $4,800.92$ tons/ha. Potential carbon stocks in this region could store $82.5 \%$ carbon at the Berau District level and $10.3 \%$ at the East Kalimantan Province level. The highest potential value of total carbon stock in this region is contributed from the secondary tropical forest ecosystem of 732,6 tons/ha $(48,1 \%)$, while the lowest value is in the teak plant ecosystem of 358,2 tons/ha $(7,2 \%)$.

The ecosystem in the Biduk-Biduk Karst Region also has the ability to absorb some carbon. The Biduk-Biduk Karst Region have a potential to absorb some carbon with the total carbon sequestration in all ecosystems of 37.33 tons/ha/year. The total carbon sequestration in all ecosystems could help to reduce carbon emissions by 7.3 $\%$ annually in Berau districts and $1.23 \%$ annually in the East Kalimantan Province. The highest potential value of total carbon sequestration in this region is contributed from the primary tropical forest ecosystem of 7.63 tons/ha/year (20.4\%), while the lowest value is in the shrub ecosystem of 0,66 tons/ha/year $(1.7 \%)$.

This research was funded by Karst Research Group-Universitas Gadjah Mada and Yayasan Kehati through TFCA Kalimantan program grant scheme entitled "Characterization and Revitalization of Important Value in SangkulirangMangkalihat Karst Region, East Kalimantan Province.

\section{References}

1. B. Griscom, P. Ellis, F.E. Putz, Carbon Emissions Performance of Commercial Logging in East Kalimantan, Indonesia, Global Change Biology, 20, 923-937 (2014)

2. K. Fujii, M. Uemura, C. Hayakawa, S. Funakawa, T. Sukartiningsih, Kosasi, S. Ohta, Fluxes of Dissolved Organic Carbon in Two Tropical Forest Ecosystems of East Kalimantan, Indonesia, Geoderma, 152, 127-136 (2009)

3. R. Lal, W. Negassa, K. Lorenz, Carbon Sequestration in Soil, Current Opinion in Enviromental Sustainability, 15, 79-86 (2015)

4. Y. Liu, C. Liu, S. Wang, K. Guo, J. Yang, X. Zhang, G. Li, Organic Carbon Storage in Four Ecosystem Types in The Karst Region of Southwestern China, Plos One, 8 (2), 1-9 (2013)

5. E. Haryono, Atmospheric Carbon Dioxide Sequestration Trough Karst Denudation Processes, Proceeding Asian Trans-disciplinary Karst Converence (2011)
6. Y. Malhi, D.D. Baldocchi, P.G. Jarvis, The Carbon Balance of Tropical, Temperate, and Boreal Forests, Plant, Cell, and Environment, 22, 715-740 (1999)

7. X.T. Lu, J.X. Yin, J.F. Qi, M.R. Jepsen, J.W. Tang, Ecosystem Carbon Storage and Partitioning in A Tropical Seasonal Forest in Southwestern China. Forest Ecology and Management, 260 (2010)

8. J.Q. Chambers, E.S. Tribuzy, L.C. Toledo, B.F. Crispim, N. Higuchi, J. Dos Santos, A.C. Araujo, B. Kruijt, A.D. Nobre, S.E. Trumbore, Respiration from a Tropical Forest Ecosystem: Partitioning of Source and Low Carbon Use Efficiency. Ecological Applications, 14 (4), 72-88 (2004)

9. C. Van der Laan, P.A. Verweij, M.J. Quinones, A.P. Faaij, Analysis of Biophysical and Anthropogenic Variables and their Relation to the Regional Spatial Variation of Above ground Biomass Illustrated for North and East Kalimantan, Borneo, Carbon Balance and Management, 9 (8), 1-12 (2014)

10. Y. Yano, K. Lajtha, P. Sollins, B.A. Caldwell, Chemical and seasonal controls on dynamics ofdissolved organic matter in a coniferous oldgrowth stand in the Pacific Northwest, USA, Biogeochemistry, 71, 197-223 (2004)

11. K. Fujii, S. Funakawa, C. Hayakawa, T. Kosaki, Contribution of different proton sources to pedogenetic soil acidification in forested ecosystems in Japan, Geoderma, 144 (3-4), 478-490 (2008)

12. J. Proctor, Tropical Litterfalls in Tropical Rain Forest, Ecological, and Management 2 (1983)

13. M. Takahashi, S. Ishizuka, S. Ugawa, Y. Sakai, H. Sakai, K. Ono, S. Hashimoto, Y. Matsuura, K. Morisada, Carbon Stock in Litter, Deadwood, and Soil in Japan's Forest Sector and Its Comparison with Carbon Stock in Agricultural Soils, Soil Science and Plant Nutrition, 56 (1), 19-30 (2010)

14. C.A.Palm, R.A.Houghton, J.M. Melillo, D.L. Skole, Atmospheric Carbondioxide from Deforestation in Southeast Asia, Biotropics, 18 (3), 177 (1986)

15. J.W. Tang, J.X. Yin, J.F. Qi, M.R. Jepsen, X.T. Lu, Ecosystem Carbon Storage of Tropical Forests over Limestone in Xishuangbanna, SW China, Journal of Tropical Forest Science, 24 (3), 399-407 (2012)

16. J. Hendri, Fluks $\mathrm{CO}_{2}$ dari Penggunaan Lahan Hutan, Teh, dan Holtikultura pada Andisol Jawa Barat, Theses Institut Pertanian Bogor (2014)

17. A. Irawan, T. June, Hubungan Iklim Mikro dan Bahan Organik Tanah dengan Emisi $\mathrm{CO}_{2}$ dari Permukaan Tanah di Hutan Alam Babahaleka Taman Nasional Lore Lindu, Sulawesi Tengah, Jurnal Agromet, 25 (1) , 1-8 (2011)

18. E. Haryono, Danardono, S. Mulatsih, S.T. Putro, T.N. Adji, The Nature of Carbon Flux in Gunungsewu Karst, Java-Indonesia, Acta Carsologica, 45 (1), 173-185 (2016) 
19. Y. Daoxian, Z. Cheng, Karst Processes and the Carbon Cycle Final Report of IGPC379 (2002)

20. H. Yang, L. Zhou, L. Huang, J. Cao, C. Groves, A Comparative Study of Soil Carbon Transfer Between Forest Soils in Subtropical Karst and Clasolite Areas and The Karst Carbon Sink Effect in Guilin, Guangxi, China, Environ Earth Science Journal, 74, 921-928 (2014) 